\title{
INTEGRASI PENDIDIKAN KARAKTER BANGSA DALAM PEMBELAJARAN SEJARAH (STUDI KASUS DI SMA AL AZHAR 3 BANDAR LAMPUNG)
}

\author{
Putut Wisnu Kurniawan \\ Program Studi Pendidikan Sejarah STKIP PGRI Bandar Lampung \\ Email: putubukan@gmail.com \\ Risna Rogamelia \\ Program Studi Bimbingan Konseling STKIP PGRI Bandar Lampung
}

\begin{abstract}
Abstrak
Hancurnya nilai-nilai moral dalam masyarakat yang ditandai dengan merebaknya kekerasan, korupsi mengakibatkan lahirnya pendidikan karakter yang perlu dikembangkan di sekolah ataupun lembaga pendidikan. Lingkungan sekolah harusnya bisa menjadi unsur terpenting bagi pertumbuhan pendidikan karakter. SMA Al Azhar 3 Bandar Lampung merupakan sekolah yang sangat mementingkan pengembangan dan pembiasaan karakter di dalam ataupun di luar proses pembelajaran. Bentuk penelitian ini adalah kualitatif deskriptif dengan strategi studi kasus ganda terpancang. Pengumpulan data dilaksanakan dengan observasi langsung, wawancara mendalam, dan pencatatan dokumen. Validasi data dilakukan dengan trianggulasi. Analisis yang digunakan adalah model analisis interaktif, yaitu pengumpulan data, reduksi data, sajian data, dan penarikan kesimpulan. Pemahaman guru tentang pendidikan karakter yang muncul di SMA Al Azhar 3 Bandar Lampung lebih menekankan pada konsep karakter Islam. Pemahaman tersebut didasari dengan ideologi yang diterapkan di sekolah masing-masing, yaitu menjadikan sekolah islami, unggul dan terpercaya. Integrasi penerapan pendidikan karakter bangsa di SMA Al Azhar 3 Bandar Lampung melalui pelajaran sejarah dianggap strategis untuk menanamkan nilai-nilai karakter bangsa kepada siswa. Keberhasilan pendidikan karakter di sekolah dapat dilihat dari dalam sikap religius, disiplin, kejujuran, kreatif, kerjasama, komunikatif, peduli, toleransi, tanggung jawab, cinta tanah air dan mandiri. Dalam penerapannya nilai-nilai religius sangat dominan dibanding nilai-nilai yang lainnya.
\end{abstract}

Kata Kunci: Pendidikan karakter bangsa, pembelajaran sejarah

\begin{abstract}
Abstraks
The destruction of moral values in a society characterized by widespread violence, corruption led to the birth of character education that needs to be developed in schools or educational institutions. The school environment should be the most important element of character education growth. SMA Al Azhar 3 Bandar Lampung which is a school that is concerned with the development and habituation of characters in the learning process or outside. The form of this study is qualitative descriptive with a stuck dual case study strategy. Data collection was conducted by direct observation, in-depth interviews, and document recording. Validation of data is done by triangulation. The analysis used is an interactive analysis model, namely data collection, data reduction, data presentation, and conclusion. The teacher's understanding of character education that emerged in SMA Al Azhar 3 Bandar Lampung emphasizes more on the concept of Islamic character. Understanding is based on the ideology applied in each school, namely to make Islamic schools, superior and reliable. The integration of the application of character education of the nation in SMA Al Azhar 3 Bandar Lampung through history lesson is a strategic lesson to instill the values of the nation's character to the students. Historical events can be taken wisdom and example in the learning process. Starting from the planning, learning process and evaluation of the character values of the nation has been created and implemented by the history teacher at Al Azhar 3 Bandar Lampung. The success of character education in schools can be seen from the religious attitude, discipline, honesty, creative, cooperation, communicative, caring, tolerance, responsibility, homeland love and independence. In its application religious values are very dominant compared to other values.
\end{abstract}

Keywords: national character education, history learning 


\section{PENDAHULUAN}

Hancurnya nilai-nilai moral dalam masyarakat yang ditandai dengan merebaknya kekerasan, korupsi mengakibatkan lahirnya pendidikan karakter yang perlu dikembangkan di sekolah ataupun lembaga pendidikan. Lingkungan sekolah harusnya bisa menjadi unsur terpenting bagi pertumbuhan pendidikan karakter. Menurut Doni Koesoema (2010) lembaga pendidikan dapat menciptakan sebuah pendekatan pendidikan karakter melalui kurikulum, penegakan disiplin, manajemen kelas, maupun melalui program-program pendidikan yang dirancang.

Dalam Kurikulum 2013 atau Kurikulum Tingkat Satuan Pendidikan (KTSP) setiap sekolah diberikan keleluasaan untuk mengembangkan atau memasukkan pendidikan karakter. Tentunya dengan adanya otonomi sekolah untuk mengembangkan kurikulum akan membuat ciri dari masing-masing sekolah. Dalam pendidikan karakter Depdiknas mewajibkan memasukan pendidikan karakter dalam proses pembelajaran. Hal ini bisa dipengaruhi ideologi sekolah dan peran para pengajar terutama dalam pengembangan dan penerapan pendidikan karakter.

SMA Al Azhar 3 Bandar Lampung yang merupakan sekolah yang sangat mementingkan pengembangan dan pembiasaan karakter di dalam ataupun di luar proses pembelajaran. Kebiasaan dan lingkungan yang baik tentunya akan mempengaruhi output siswa. Hal inilah yang harus ditingkatkankan di masa sekarang dimana banyak terjadi kenakalan remaja. Topik inilah yang akan menjadi kajian penulis untuk diteliti lebih lanjut. Dengan adanya inovasi guru tersebut, diharapkan siswa lebih mudah dalam mengkomunikasikan materi yang akan dipelajari.

Orang yang memiliki karakter kuat adalah mereka yang tidak mau dikuasai oleh sekumpulan kenyataan yang telah ada begitu saja dari asalnya. Sedangkan, orang yang memiliki karakter lemah adalah orang yang tunduk pada sekumpulan kondisi yang telah diberikan kepadanya tanpa dapat menguasainya. Orang yang berkarakter adalah seperti orang yang membangun dan merancang masa depannya sendiri. Dia tidak mau dikuasai oleh keadaan kodratinya yang menghambat pertumbuhannya. Sebaliknya, dia menguasai, mengembangkannya demi kesempurnaan kemanusiaannya (Doni Koesoema, 2007: 91).

Menurut Mounir yang dikutip Doni Koesoema (2007: 90-91) bahwa karakter dapat dilihat dari dua hal yaitu pertama sebagai sekumpulan kondisi yang telah diberikan begitu saja atau telah ada begitu saja, yang lebih kurang 
dipaksakan dalam diri kita. Karakter yang demikian dianggap sebagai sesuatu yang telah ada dari sononya (given). Kedua, karakter juga bisa dipahami sebagai tingkat kekuatan melalui seorang pribadi mampu menguasai keadaan tersebut. Karakter yang demikian ini disebutnya sebagai sebuah proses yang dikehendaki (willed).

Secara umum menurut Marzuki (2011: 95), karakter merupakan nilainilai perilaku manusia yang universal atau umum yang meliputi seluruh aktifitas manusia, baik dalam rangka berhubungan dengan Tuhannya, dirinya, sesama manusia, maupun lingkungannya, yang terwujud dalam pikiran, sikap, perasaan, perkataan, dan perbuatan berdasarkan norma-norma agama, hukum, tata krama, budaya, dan adat istiadat. Dari konsep karakter inilah muncul konsep pendidikan karakter (character education).

Allport dikutip dalam Ki Fudyartanta (1998: 4) berpendapat bahwa “...character is personality evaluated, and personality is character devaluated...." artinya bahwa karakter atau watak adalah kepribadian yang dinilai dan kepribadian adalah karakter yang tidak dinilai. Jelasnya bahwa kepribadian yang telah terlibat dengan nilai-nilai budaya manusia ini maka terbentuklah watak. Konkritnya, bahwa setiap tingkah laku manusia termasuk penyesuaiannya di dalam masyarakat pasti berhadapan atau berdasarkan nilainilai tertentu. Misalnya seseorang memberi uang kepada pengemis, seseorang menolong temannya dan sebagainya.

Socrates berpendapat tentang karakter yaitu “...identified virtue with ethical knowledge (specifically, with knowledge of which things are intrinsically good and intrinsically evil), and so maintained that the truly virtuous consistently act virtuously....", Erik J. (2006: 462). Socrates menjelaskan bahwa kebajikan atau kebaikan itu berhubungan dengan pengetahuan etika yang dimiliki (khususnya dengan pengetahuan yang hal-hal yang baik dan jahat), dan mempertahankan bahwa benar-benar bertindak berbudi pekerti secara konsisten. Artinya perlu ada pemahaman dari manusia dalam melakukan kebaikan, sehingga mengerti baik dan buruk serta manusia harus bisa mempertahankan secara tetap.

Pengertian di atas lebih lanjut dijelaskan Thomas Lickona mengenai unsur-unsur untuk membentuk karakter yang baik. Menurut Thomas Lickona (1991: 51) sebagai berikut:

Character so conceived has three interrelated parts: moral knowing, moral feeling and moral behavior. Good character consists of knowing the good, desiring the good, and doing the good, habits of the mind, habits of the heart 
and habits of action. All three are necessary for leading a moral life; all three make up moral maturity. When we think about the kind of character we want to children , it's clear that we want them to be able to judge what is right, car deeply about what is right, and then do what they believe to be right even in the face of pressure from without and temptation from within.

Dari penjelasan Thomas Lickona karakter memiliki tiga bagian yang saling berhubungan yaitu pengetahuan moral, perasaan moral dan perilaku moral. Karakter yang baik terdiri dari mengetahui moral yang baik terlebih dahulu, menginginkan orang berbuat baik dan melakukan kebiasaan baik dari pikiran dan kebiasaan tindakan. Ketiganya diperlukan untuk memimpin sebuah kehidupan moral serta membentuk kematangan moral ketika berpikir tentang jenis karakter, pengajar ingin anak-anak jelas bahwa ada keinginan mereka bisa menilai apa yang benar, kemudian mendalami tentang apa yang benar dan kemudian melakukan apa yang mereka yakini benar bahkan dalam menghadapi tekanan dari luar dan godaan dari dalam.

Menurut Thomas Lickona, (2004: 7) tentang karakter yang baik adalah sebagai berikut.

The content of good character is virtue. Virtues such as honesty, justice, courage, and compassion are dispositions to behave in amorally good way. They are affirmed by societies and religions around the world. Because they are intrinsically good, they have a claim on our conscience. Virtues transcend time and culture (although their cultural expression may vary); justice and kindness, for example, will always and everywhere be virtues, regardless of how many people exhibit them.

Thomas Lickona menekankan isi dari karakter yang baik adalah kebajikan. Kebajikan dapat dicontohkan dengan sikap kejujuran, keadilan, keberanian dan belas kasih adalah perilaku atau sikap yang baik. Dijelaskan juga secara terkandung bahwa dalam masyarakat dan nilai-nilai agama dapat mempengaruhi karakter. Menurut Thomas Lickona (1991: 53) komponen untuk membentuk karakter yang baik adalah sebagai berikut.

Pendidikan karakter dimaknai sebagai keseluruhan dinamika rasional antar pribadi dengan berbagai macam dimensi, baik dari dalam maupun dari luar dirinya, agar pribadi itu semakin dapat menghayati kebebasannya sehingga ia dapat semakin bertanggungjawab atas pertumbuhan dirinya sendiri sebagai pribadi dan perkembangan orang lain dalam hidup mereka, (Sri Haryati, 2011: 5-6).

Menurut Samsuri (2011: 8) pendidikan karakter hendaknya mencakup aspek pembentukan kepribadian yang membuat dimensi nilai- 
nilai kebajikan universal dan kesadaran kultural dimana norma-norma kehidupan itu tumbuh dan berkembang. Pendidikan karakter mampu membuat kesadaran individu untuk berperilaku dalam kehidupan sosial atau masyarakat.

Dalam kehidupan masyarakat Mastuhu (2003: 136) berpendapat bahwa pendidikan bisa mengembangkan human dignity yaitu harkat dan martabat manusia atau humaniziny human yaitu memanusiakan manusia sehingga benarbenar mampu menjadi khalifah di muka bumi. Sifat menghargai, toleransi dan mampu menjadi teladan baik merupakan ciri dari konsep yang diusung dari pendidikan karakter.

Yudi Latief yang dikutip Sabar Budi Raharjo (2010: 232) berpendapat pendidikan karakter adalah suatu payung istilah yang menjelaskan berbagai aspek pengajaran dan pembelajaran bagi perkembangan sosial. Lebih lanjut dikemukakan bahwa pendidikan karakter adalah suatu pendekatan holistik yang menghubungkan dimensi moral dengan ranah sosial dan sipil dari kehidupan peserta didik.

$$
\text { Dalam pengertian makna }
$$
pendidikan karakter di sekolah, semua komponen (stakeholders) harus dilibatkan, termasuk komponenkomponen pendidikan itu sendiri, yaitu isi kurikulum, proses pembelajaran dan penilaian, kualitas hubungan, penanganan atau pengelolaan mata pelajaran, pengelolaan sekolah, pelaksanaan aktivitas atau kegiatan kokurikuler, pemberdayaan sarana prasarana, pembiayaan, dan etos kerja seluruh warga dan lingkungan sekolah.

Lebih lanjut, Maksudin (2012: 4) menambahkan pendidikan karakter adalah suatu sistem penanaman nilainilai karakter kepada warga sekolah yang meliputi komponen pengetahuan, kesadaran atau kemauan dan tindakan untuk melaksanakan nilai-nilai tersebut, baik kepada Tuhan Yang Maha Esa, diri sendiri, sesama, lingkungan maupun kebangsaan. Pendidikan karakter merupakan suatu penanaman dan pengembangan nilai-nilai dalam diri peserta didik yang tidak harus merupakan satu program atau pelajaran secara khusus.

\section{METODE PENELITIAN}

Jenis penelitian yang digunakan adalah penelitian kualitatif deskriptif. Untuk mengumpulkan data dalam kegiatan penelitian diperlukan cara-cara atau teknik pengumpulan data tertentu. Sesuai dengan bentuk penelitian kualitatif deskriptif, maka teknik pengumpulan data yang digunakan dalam penelitian ini observasi langsung, wawancara mendalam dan mencatat dokumen. Dalam penelitian ini teknik trianggulasi yang digunakan adalah 
trianggulasi data (data trianggulation) dan trianggulasi metode (methodological trianggulation). Dalam proses analisis terdapat tiga komponen yang harus dipahami oleh para peneliti yaitu (1) pengumpulan data, (2) reduksi data, (3) sajian data (4) penarikan simpulan/ verifikasi.

\section{HASIL PENELITIAN}

\section{Pemahaman Guru Mengenai Pendidikan}

\section{Karakter Bangsa}

Guru merupakan faktor terpenting dalam proses penerapan pendidikan karakter di sekolah. Guru mempunyai tugas sebagai seorang pendidik dan menjadi pengganti orang tua di sekolah. Guru dapat dikatakan sebagai agen kebaikan atau agen perubahan, karena dengan posisi yang strategis guru bisa mengarahkan dan membentuk karakter siswa. Hal inilah yang menjadi salah satu alasan guru harus mempunyai pemahaman yang baik tentang pendidikan karakter. Dengan pemahaman atau pandangan yang baik maka akan mudah dalam pelaksanaan pendidikan karakter di kelas. Upaya untuk melihat tingkat pemahaman atau persepsi guru terhadap pendidikan karakter bangsa diharapkan untuk dapat mengetahui sejauh mana guru memahami pendidikan karakter bangsa yang sudah berjalan di sekolah.

Pada waktu wawancara dengan guru di SMA Al Azhar 3 Bandar Lampung sebagian cukup menguasai apa arti dan hakekat pendidikan karakter. Sebagian besar dari guru yang diwawancarai mampu menghubungkan antara mata pelajaran yang diampu dengan pendidikan karakter bangsa sesuai dengan tujuan kurikulum 2013. Mereka sadar bahwa pendidikan karakter bangsa sangat dibutuhkan dalam proses pendidikan di sekolah. Sehubungan ada sebagian guru yang telah baik menunjukkan komitmen dan pemahaman mengenai profesinya, sejarah sekolah dan pemahaman mereka terhadap pendidikan karakter.

$$
\text { Pelajaran di SMA Al Azhar } 3
$$

Bandar Lampung memuat nilai-nilai religius. Pelajaran yang bermuatan Agama Islam tersebut dapat menguatkan karakter siswa, yang tercermin dari berbagai aspek. Pendekatan Islam salah satu cara untuk menguatkan karakter. Dalam Islam tidak ada disiplin ilmu yang terpisah dari etika Islam. Nilai-nilai agama tidak berhenti pada proses ritual saja, melainkan proses aktualisasi di masyarakat luas. Dengan landasan dan keimanan yang kuat maka akan menjadi pondasi yang kokoh untuk membentuk karakter. Pengaruh yang lain adalah kegiatan ekstrakurikuler. Kegiatan ini akan membentuk kepemimpinan dan jiwa-jiwa yang positif dikarenakan adanya potensi karakter yang baik di setiap kegiatan ekstrakurikuler.

Budaya yang dikembangkan sekolah dapat mempengaruhi pola piker 
guru dan siswa. Dalam sekolah siswa akan terbiasa dengan suasana-suasana Islam, sehingga pemahaman mereka tentang nilai-nilai Islam sangat baik. Hal tersebut menjadi kelebihan tersendiri bagi siswa di SMA Al Azhar 3 Bandar Lampung karena selain mereka dapat memahami pelajaran umum, mereka juga baik dalam penguasaan dan pemahaman keilmuan agama Islam.

Dengan pelaksanaan kurikulum 2013 dan penguatan karakter Islam membuat sekolah mempunyai nilai lebih. Penguasaan ilmu pengetahuan dan ketakwaan menjadi parameter untuk selalu menjadi nilai lebih dalam sebuah lembaga pendidikan. Oleh karena itu keseimbangan antara nilai-nilai pengetahuan umum dan nilai-nilai Islam menjadi prioritas dalam pengembangan siswa.

Menurut Thomas Lickona, untuk mendapatkan karakter baik maka perlu adanya komponen moral knowing, moral feeling dan moral action. Moral knowing yang dimaksud adalah pemahaman mengenai pendidikan karakter itu sendiri. Apabila persepsi baik guru dan siswa mengenai pendidikan karakter bangsa baik, maka akan mendukung proses implementasi atau penerapan pendidikan karakter yang diharapkan. Nilai yang akan disalurkan juga tergantung sesuai dengan pemahaman masing-masing. Apabila semua komponen mempunyai visi dan misi dan didukung oleh persepsi guru terhadap orientasi sekolah, maka siswa akan terbentuk sesuai yang diharapkan.

Integrasi Penerapan Pendidikan Karakter Bangsa Dalam Pembelajaran Sejarah di SMA Al Azhar 3 Bandar Lampung

SMA Al Azhar 3 Bandar Lampung merupakan sekolah yang sangat potensial untuk pengembangan pendidikan karakter. Pola penerapan pendidikan karakter bisa dilaksanakan dalam kegiatan ekstrakurikuler, proses kegiatan belajar mengajar, lingkungan yang kondusif dan keteladanan guru (guru) ataupun pelajaran-pelajaran yang bisa memberikan pemahaman dan dorongan untuk berbuat baik.

$$
\text { Pendidikan karakter di sekolah }
$$
lebih banyak berurusan dengan penanaman nilai-nilai budi pekerti luhur. Untuk mencapai pertumbuhan integral dalam pendidikan karakter, perlu dipertimbangkan berbagai macam pola yang membantu terwujudnya pendidikan karakter yang efektif. Pola ini bisa menjadi unsur-unsur yang sangat penting bagi pendidikan karakter di sekolah. Unsur-unsur tersebut antara lain landasan sekolah, penanaman karakter, keteladanan dan pengembangan karakter. 
Pendidikan karakter menghimpun banyak kumpulan nilai-nilai yang dianggap penting bagi pelaksanaan dan realisasi visi lembaga pendidikan. Lembaga pendidikan harus mampu menentukan perilaku standar yang menjadi prioritas khas lembaga tersebut. SMA Al Azhar 3 merupakan sebuah lembaga pendidikan yang mempunyai visi besar. Visi besar dari yayasan SMA Al Azhar 3 Bandar Lampung adalah "Mewujudkan Sekolah Unggul, Islami, dan Terpercaya."

Dari Visi Misi serta tujuan sekolah dapat diketahui bahwa sekolah juga mengedepankan nilai-nilai karakter atau akhlakul karimah dalam kurikulumnya. Sekolah mewajibkan guru ketika dalam mengajar atau melaksanakan kegiatan belajar mengajar bukan hanya menyampaikan materi tetapi mendidik siswa supaya mempunyai akhlak yang baik di kelas.

Dalam pelajaran sejarah sendiri, muatan pendidikan karakter diharapkan mampu membangun jiwa nasioanalisme, patriotism serta nilai-nilai positif lainnya. Dalam pembelajarannya di SMA Al Azhar 3 Bandar Lampung sudah menggunakan kurikulum 2013 sehingga pendidikan karakter wajib dimasukkan dalam muatan pelajaran, termasuk pelajaran sejarah.

Dalam

perencanaan pembelajaran atau Rencana Pelaksanaan
Pembelajaran (RPP) dilengkapi dengan nilai-nilai karakter yang diharapkan. Karakter yang dibuat disesuaikan dengan setiap indikator kompetnsi yang akan disampaikan. Pembuatan rencana pelaksanaan pembelajaran atau RPP akan membantu guru dalam menyampaikan materi.

Dalam penyampaian materi, guru sejarah di SMA Al Azhar 3 Bandar Lampung selalu menyampaikan nilai-nilai moral baik di pertengahan atau di akhir pembelajaran. Harapannya siswa dapat meneladani, mengambil hikmah atas peristiwa masa lalu yang telah diajarkan oleh guru. Dengan seperti itu maka diharapkan semangat nasionalisme, patriotisme dapat muncul dalam pembelajaran sejarah.

Nilai-nilai karakter lainnya dapat dilihat juga dalam proses pembelajaran sejarah. Salah satunya ketika dalam diskusi kelompok. Nilai kerjasama, tanggungjawab dan toleransi terlihat dalam diskusi tersebut. Siswa sadar bahwa mereka ketika tampil akan diberikan penilaian lebih oleh guru. Oleh karenanya siswa-siswi ingin menunjukkan yang terbaik dalam berdiskusi kelompok.

Dalam penilaian guru tidak hanya sekedar melihat dari aspek kognitif (pengetahuan) saja, melainkan juga aspek sikap, hal ini dalam rangka mendukung implementasi pendidikan karakter bangsa dalam kurikulum dan 
juga tujuan serta visi misi sekolah yang menjadikan sekolah Unggul, Islami dan terpercaya.

Keteladanan dipandang sebagai model efektif untuk menumbukan sikap positif dalam membangun karakter bangsa, karena melemahnya karakter pemuda misalnya sebagai aset masa depan Indonesia salah satu sebabnya karena krisis keteladanan. Maka, para pemimpin bangsa harus mampu mengimplementasikan ajaran budi pekerti luhur, akhlak Islam dan Pancasila dalam kehidupan sehari-hari. Dan semua itu menjadi tanggung jawab bersama semua komponen bangsa. Dalam ruang lingkup kecil (sekolah), guru atau guru yang menjadi tokoh utama dalam penanaman dan memberikan teladan kepada muridnya (Kuswono, K., 2013: 48).

Melakukan refleksi pada setiap kali pembelajaran merupakan salah satu cara menanamkan nilai karakter kepada siswa. Refleksi bisa diartikan mencari hikmah yang di dapat dalam peristiwa sejarah. Sejarah menceritakan peristiwa masa lalu yang sangat berpengaruh terhada bangsa atau manusia itu sendiri. Oleh karena itu masa lalu bisa dijadikan cermin bagi siswa untuk mengambil nilai-nilai yang baik dan meninggalkan nilai-nilai yang buruk dalam peristiwa sejarah.

Sejarah bukan hanya berbicara masalah tahun, tanggal dan tempat, akan tetapi dalam pembelajaran sejarah guru harus mampu memberikan value atau nilai khususnya untuk meningkatkan semangat nasionalisme. Dengan sejarah siswa akan mengetahui sejarah dan kebesaran bangsanya. Sejarah merupakan pelajaran yang strategis untuk menanamkan nilai-nilai karakter bangsa disamping pelajaran lainnya seperti pelajaran Agama, Pendidikan Kewarganegaraan.

Menurut Thomas Lickona, untuk mendapatkan karakter yang baik harus melalui penanaman moral yang baik (moral knowing), kemudian mencintai kebaikan (moral feeling), dan melakukan kebaikan (moral action). Pengertian tersebut berarti pendidikan karakter bukan hanya sekedar mengajarkan karakter kepada siswa atau anak, melainkan pendidikan karakter juga menanamkan kebiasaan (habituation) yang baik sehingga siswa bisa mengetahui, merasakan dan mau melakukan kebaikan.

Dari unsur tersebut SMA Al Azhar 3 Bandar Lampung sudah melaksanakan konsep dari Thomas Lickona. Dalam pengembangan penanaman moral di masukkan ke semua mata pelajaran khususnya mata pelajaran Sejarah. Dengan adanya pelajaran tersebut maka siswa diharapkan dapat mencintai dan kemudian mau melakukan kebaikan 
sebagai aktualisasi atau pengamalan siswa dalam kegiatan sehari-hari.

\section{Keberhasilan Siswa dalam Menerapkan} Nilai-Nilai Pendidikan Karakter di SMA

\section{Al Azhar 3 Bandar Lampung}

Pendidikan karakter merupakan suatu proses yang menghubungkan dimensi moral dengan ranah sosial dalam kehidupan siswa sebagai pondasi dasar terbentuknya generasi yang mempunyai karakter yang baik. Sekolah merupakan tempat yang efektif sebagai pembentukan karakter individu sehingga mereka dapat tumbuh dan berkembang dengan baik dalam lingkungannya. Lingkungan sekolah dapat menjadi tempat pendidikan yang baik bagi pertumbuhan karakter siswa. Pendidikan karakter akan lebih cepat berkembang apabila semua komponen dan kegiatan sekolah dapat diintegrasikan dalam program pembentukan karakter atau budi pekerti yang baik.

Lembaga pendidikan merupakan salah satu wahana untuk menanamkan pengertian nilai-nilai moral, membentuk dan melatih siswa dalam berperilaku yang baik. Sekolah juga sebagai wahana bagi praksis pendidikan nilai. Dalam sekolah diharapkan siswa belajar mengaktualisasikan nilai-nilai yang telah mereka dapatkan. Keberhasilan pendidikan karakter di sekolah dapat dilihat dari aktualisasi siswa berupa sikap atau tindakan yang terlihat, bukan hanya sekedar pemahaman teoritis saja.

Aktualisasi dalam diri siswa berupa perwujudan tindakan dan sikap inilah yang menjadi salah satu acuan keberhasilan pendidikan karakter yang diterapkan di sekolah. Kurang lebih terdapat 18 nilai pendidikan karakter yang bisa dikembangkan di sekolah. Nilai-nilai tersebut antara lain religius, jujur, toleransi, disiplin, kerja keras, kreatif, mandiri, demokratis, rasa ingin tahu, semangat kebangsaan, cinta tanah air, menghargai prestasi, bersahabat atau komunikatif, cinta damai, gemar membaca, peduli lingkungan, peduli sosial dan tanggung jawab. Dari nilai-nilai tersebut bisa berkembang lagi sesuai dengan kondisi dan tujuan sekolah masing-masing.

Pola penerapan pendidikan karakter, persepsi guru dan budaya sekolah akan mempengaruhi aktualisasi nilai karakter pada siswa di sekolah. Dalam SMA Al Azhar 3 Bandar Lampung sikap atau karakter siswa yang terlihat meliputi religius, disiplin, kejujuran, kreatif, kerjasama, komunikatif, peduli dan cinta tanah air. Nilai-nilai tersebut bisa terlihat dalam kegiatan siswa baik di dalam kelas atau di luar kelas.

Nilai-nilai di atas merupakan contoh aktualisasi nilai-nilai karakter pada siswa di SMA Al Azhar 3 Bandar 
Lampung. Nilai-nilai karakter tersebut bisa muncul dari budaya sekolah, keteladanan dan dorongan dari sekolah. Nilai budi pekerti luhur atau akhlak mulia seharusnya bukan hanya diajarkan di sekolah melainkan harus dilaksanakan dalam setiap kesempatan. Lingkungan yang baik maka akan membentuk karakter yang baik juga.

\section{PENUTUP}

\section{Simpulan}

Pemahaman guru tentang pendidikan karakter yang muncul di SMA Al Azhar 3 Bandar Lampung lebih menekankan pada konsep menekankan pada karakter Islam. Integrasi penerapan pendidikan karakter di SMA Al Azhar 3 Bandar Lampung menggunakan pola melalui kurikulum pembelajaran (terdapat pelajaran Islam yang mengajarkan akhlak, Pkn, Sejarah), budaya sekolah, kegiatan estrakurikuler, dan keteladanan guru.

Pelajaran sejarah merupakan pelajaran yang strategis untuk menanamkan nilai-nilai karakter bangsa kepada siswa. Peristiwa sejarah bisa diambil hikmah dan teladannya dalam proses pembelajaran. Mulai dari perencanaan, proses pembelajaran dan evaluasi nilai-nilai karakter bangsa sudah dibuat dan dilaksanakan oleh guru sejarah di SMA Al Azhar 3 Bandar Lampung.
Keberhasilan pendidikan karakter di sekolah dapat dilihat dari aktualisasi (pengamalan) siswa yaitu meliputi religius, disiplin, kejujuran, kreatif, kerjasama, komunikatif, peduli, toleransi, tanggung jawab, cinta tanah air dan mandiri. Dalam penerapannya nilai-nilai religius sangat dominan disbanding nilai-nilai yang lainnya.

\section{DAFTAR PUSTAKA}

Abdul Majid dan Dian Andayani. (2011). Pendidikan Karakter: Perspektif Islam. Bandung: Remaja Rosdakarya.

Abuddin Nata. (2001). Sejarah Pertumbuhan dan Perkembangan Lembaga-Lembaga Pendidikan Islam di Indonesia. Jakarta: Grasindo.

Doni Koesoma. (2007). Pendidikan Karakter (Strategi Mendidik Anak di Zaman Global). Jakarta: Grasindo.

Dhofier, Zamakhsyari. (1985). Tradisi Pesantren: Studi Tentang Pandangan Hidup Kyai. Jakarta: LP3ES.

Hasbullah. (1999). Sejarah Pendidikan Islam di Indonesia: Lintasan Sejarah Pertumbuhan dan Perkembangan. Jakarta: Raja Grafindo Persada.

Hendra Sugiantoro (edt). (2010). Pendidikan Profetik: Revolusi Manusia Abad 21, Yogyakarta: Education Center BEM REMA UNY.

Jajat Burhanudin dan Ahmad Baedowi. (2003). Transformasi Otoritas Keagamaan: Pengalaman Islam di Indonesia. Jakarta: Gramedia.

Ki Fudyartanta. (2010). Membangun Kepribadian dan Watak Bangsa Indonesia. Yogyakarta: Pustaka Pelajar. 
Kuntowijoyo. (2008). Paradigma Islam (Interpretasi untuk Aksi). Bandung: Mizan.

Kuswono, K. (2013). Character Education Muhammadiyah Pattern (Case Study SMA Muhammadiyah 1 and MA Muallimin Yogyakarta). GUIDENA: Jurnal Ilmu Pendidikan, Psikologi, Bimbingan dan Konseling, 3(1), 4249.

Lickona, Thomas. (1991). Educating for Character: How Our Schools can Teach Respect and Responsibility. New York: Batam Book.

Lickona, Thomas. (2004). Character Matters: How To Help Our Children Develop Good Judgment, Integrity And Other Essential Virtues. New York: Rockefeller Centre.

Mastuhu. (2003). Menata Ulang Sistem Pendidikan Nasional dalam Abad 21. Yogyakarta: Safiria Insania.

Mohammad Firdaus. (1998). Sistem Pendidikan Pesantren: Telaah Evaluatif Sistem Pendidikan Pesantren. Yogyakarta: Universitas Islam Indonesia.

Moleong. (2005). Metodologi Penelitian Kualitatif. Bandung: Rosda.

Mujamil Qomar. (2005). Epistomologi Pendidikan Islam dari Metode Rasional hingga Metode Kritik. Jakarta: Erlangga.

Samsuri. (2011). Pendidikan Karakter Warga Negara (Kritik Pembangunan Karakter Bangsa). Yogyakarta: Diandra Pustaka Indonesia.

Sukarno. (2005). Di Bawah Bendera Revolusi (Jilid I). Jakarta: Yayasan Bung Karno

Sutopo, HB. (2006). Metodologi Penelitian Kualitatif. Surakarta: UNS Press.

Suwendi. (2004). Sejarah dan Pemikiran Pendidikan Islam. Jakarta: Grafindo Persada. 